\title{
Risk management analysis of network loan platform
}

\author{
Dan Zhang ${ }^{1, a}$ \\ ${ }^{1}$ School of Economic Management, Jilin Agricultural Science and Technology University, No. 77 \\ hanlin road, jilin economic and technological development zone, Jilin ,Jilin132101 ,China \\ a jiuzhanzhangdan@163.com
}

Keywords: network loan, risk management, development

Abstract. Network loan platform has become the main mode of Internet finance, it provides its capital suppliers and demanders with convenient and efficient financing channels, but also advances the vigorous development of the financial industry. In this paper, there is analysis of risk of network loan platform and the current situation, which puts forward the corresponding countermeasures for network credit risk and these will promote the healthy development of Internet finance.

\section{Introduction}

P2P originated from MicroCredit mode in 1974 at Bangladesh founded by Mohamed Yunus who was also awarded the Nobel prize. P2P's essence is that it's an Internet financial mode that individual or enterprise go through the third party financial platform for loan to finance. After the founding of China's first network loan platform 'paipai loan' in 2007.Network loan platform went into a tepid stage and shortly after 2010, with the rapid development of the Internet , became the main platform for personal and business loans.

\section{The Current Situation of Network Loan}

\section{The Number and Distribution of Network Loan Platform}

From 2007 to 2010 there was an primary stage of the development of network loan platform, while in 2010, the number of online loan platform did not exceed 10. From 2011 to 2015 there was a rapid stage of network loan platform development which increased from 50 ones in 2011 to 2595 ones in 2015. Then in 2016 net loan platform entered the stage of specification development, at the end of December 2016 .net loan platforms amounted to 2448 of normal operation . At the end of December 2016, the top three number of network loan platforms in normal service within all are Guangdong Province, Beijing City and Shanghai City whose numbers are diversely 473, 461, 331, accounting for $51.67 \%$ of the total number of the platforms, $46.64 \%$ in the same period in 2015 . The data indicates that some positive network loan platforms focus development on some regions densely. At the end of 2016, the number of normal operation platforms in Zhejiang, Shandong and Jiangsu three areas are over 100 whose number are, respectively, 280, 118 and 30. Amongst 30 provinces and cities, in Ningxia, Jilin, Heilongjiang, Gansu, Hainan, Qinghai, the number of network loan platform in service is not more than 10 .

\section{Network Loan Volume Increases Year by Year}

From the beginning of 2013, loan volume increases, in 2016 the network loan industry turnover exceeded 2 trillion RMB, reached 2 trillion and 63 billion 872 million RMB, in comparison to the full year 2015 network loan volume (982 billion 300 million RMB) increased by $110 \%$. According to statistics, Network loan industry volume of the top 100 of all platforms accounted for $78 \%$ of the entire industry turnover proportion ; the top 200 of all platforms trading volume accounted for $87 \%$; the top 300 of all platforms turnover accounted for more than $91 \%$, which indicates that the trading volume of network loan platform present a dense trend.

\section{Network Loan Platform's Loan Balance}

With the turnover increasing steadily, network loan industry balance is equally to rise. By the end of 2016, the total loan balance of network loan industry has reached 816 billion 224 million RMB, and increase $100.99 \%$ compared to 2015, which indicates that hundreds of billions dollar funding came 
into the network loan industry in one year time. According to statistics, the number of lenders whose amount of investment is 0 to ten thousand is the top, which accounts for $50.31 \%$, and ones who invest ten to hundred accounted for 35.23\%, the number of investment more than 1 million accounted for $1.29 \%$.

\section{Loan Period of Network Loan Platform}

In 2016, the average loan period of network loan industry amounted up to 7.89 months. Among others, the shortest period is 4.73 months in 2013 . Shortly after 2013 it increased constantly year by year, and the main reason is that the high turnover in large platforms extended average term of loan platform across the whole industry.

\section{The Risk in Existence of Network Loan}

\section{Default Risk}

one is break of the capital chain of platform, because of the borrower's credit default, not timely repayment of loans, influence on platform circulation, platform could not timely repay the principal and interest of investors, leads investors draw money in rush, eventually led to the collapse of the platform. Secondly, network loan platform operates worse with bad management. The platform contributes a lot of money to long-period, high-risk loan projects, resulting in funds can not be withdrawn in time, let alone without professional personnel supervising and managing on the use of funds. Thirdly, some criminals aim to store money using network loan platform. To attract investors, they at first give investors a certain high interest and run away when the money accumulated to a certain scale. Fourthly, network loan platform have risks of control. The risk manager is lacking in experience and ability to take appropriate and timely measures and methods to eliminate or reduce the occurrence of risk events or to reduce the loss caused by the occurrence of risk events.

\section{Circulation Risk}

Circulation risk of network loan platform mainly comes from the risk of platform not getting adequate funding to pay the due debt. Many network loan platforms by high interest rates attract investment funds, blind lending or illegal misappropriation, because after the network platform having absorbed funds, they did not retain sufficient circulation risk reserve, thus resulting in the low circulation and when the capital chain rupture, investors cannot handle large withdrawals situation.

\section{Moral Risk}

Network loan company is contributing towards banking in abnormal forms, but the truth is it does not have the qualifications and ability to engage in banking business, let alone approval of financial business given by relevant departments and are not included in the bank's credit system, could not inquire the borrower's credit record via credit system in the central bank. If loss appears, borrowers cannot be included in the borrower's information in the bank credit loan system. Compared with the bank, platform lacks of management capacity and control of the misappropriation of funds of unethical behavior and effective guarantee of the investor funds safety. So investors are forced to undertake uncertain moral risk the network loan platform contains .

\section{Network Security Risk}

Since the network loan platform refers to investors and borrowers personal information, borrowed money and other confidential information, so we must ensure the safety of network loan platform. If, on the network platform's system, related information about software and data on the hard disk are damaged or stolen, not only it affects the interests of investors and borrowers, but network loan platform security will be questioned, and this could lead to customers withdrawing money densely. P2P network loan platform must ensure the integrity, availability,authenticity and confidentiality of information. Many network loan platforms lack of professional network security personnel, with low network risk awareness, resulting in invasion of network viruses and hackers. 


\section{Precautions Against the Risk of Network Loan}

\section{Pay Risk Reserve}

The network loan company must ensure interests of investors by establishing loan loss provision system according to proportion of the borrower's financial risk, which can also comes from the company's network loan profit and own capital. By the end of December 2015,network loan companies that had set up loss loan provision system had not reached more than $20 \%$. In order to prevent and reduce risks,network loan companies should reach full coverage, and set up a loss loan provision escrow account in the charge of banks and other financial institutions. When facing risk, loan loss provision system make payments to investors, and then find out the cause of problems, to prevent the network loan company from crisis of confidence once again.

\section{Strengthen Supervision, Information Disclosure}

In the United States, network loan company is regulated by the securities and Exchange Commission, while in the UK it is supervised by the government, but in China the network loan platform is under joint supervision by the five departments, including the CBRC, the Ministry of industry, Ministry of public security, network information office and local finance office of. ${ }^{[1]}$ The regulated contents of network loan company and platform should include: the supervision specially set up on network loan companies ; supervision on assets and liabilities of the network loan company; supervision on the market access, market financing, market interest rates, the market rules ; supervision on the accounting of company; supervision on network loan company debt; supervision on network loan company's financial products and financial tools. The main point is to focus on the scope of business, market access and network loan risk control, capital circulation and crisis management. The network loan platform should strengthen information disclosure, including two aspects: one is its own information, such as the company's registered capital, business license, tax registration certificate, organization code certificate, account verification, company executives, annual report on company's business operations. Two is the information about borrower and loan financing project, including project loan contract, transaction amount, transaction number, loan balances, the amount of overdue loans, overdue loans rate, loan default rate, the number of lenders and borrowers. ${ }^{[2]}$

\section{Improve the Laws and Regulations of Network Loan}

Customer funds must be taken into custody by third party bank, put one file and take on management of negative list, set borrowing maximum limit for individual borrower . These methods aim to make network loan function to prevent the risk to a certain extent, but the fact is that large financing needs for funds in the practice cannot be guaranteed so, scientific adjustments should be made according to the market demand and specific problems in practice.In addition , interim measures couldn't clarify business license system for network loan company. Because the network finance involves issues of capital flow and social economy stability, China should introduce relevant laws in detail to improve and regulate the illegal cost of network loan companies and borrowers, strengthen the legal awareness of illegal enterprises and individuals.

\section{Input into Network Security Technology}

Network loan platform must take advantage of the network firewall technology to effectively monitor computer, ensure the normal use of the management system. In the process of borrowing and lending operation of funds, it should carry out effective authentication. If under permission conditions, then the firewall can let the packet in.Network loan company should vigorously train more maintenance personnel, to increase network security maintenance work, and constantly to improve the network loan system design. Network loan company should make more use of network system software to build a more perfect access control, storage protection and management function, and to prevent the power stored beyond authority and storage area outside the risk of being read and written,and to offer both sides of the data file access to provide monitoring and protection. ${ }^{[3]}$

\section{Improve the Loan Platform Credit System}

Financial data will be a useful tool to promote the development of network loan platform. Especially in the credit system, network loan company should cooperate with other credit institutions or data company, well-known businesses to increase the comprehension about borrower information, to 
make good use of Big data analyzing, digging, extracting, borrower's credit status, analyze the credit behavior, loan psychology and repayment ability, to track records of the funds, effectively ensure the safety of investor funds.

\section{Conclusions}

For the development of the network loan platform, the network lending companies need to strengthen the innovation of products. Internet companies should pay attention to the creation of their own brand, so that the company credit could enjoy more support from investors, acquire more customers, and promote the loan industry prosperity and rapid development.

\section{References}

[1] Xun Qiu, Shen Rui.P2P network lending industry local regulatory issues and Countermeasures . China: financial education research(2017).p47-53

[2] Yanhua Wang.P2P network lending development of legal difficulties and regulatory measures . China: Journal of Jilin Institute of business and technology(2016).p90-94

[3] Haiguang Li. Computer network security technology and prevention strategy . China: electronic technology and software engineering(2017). p210-211. 